\title{
Comparison of the Biological Activity and Constituents in Japanese Ambers
}

\author{
Eisaku Shimizu ${ }^{*}$, Nozomu Shimoda ${ }^{*}$, Tetsuaki Kawamura1, Naomi Ueda ${ }^{2}$, Ken-ichi Kimura ${ }^{1 \#}$ \\ ${ }^{1}$ Graduate School of Arts and Sciences, Iwate University, Morioka, Japan \\ ${ }^{2}$ Gangoji Institute for Research of Cultural Property, Nara, Japan \\ Email: "kimurak@iwate-u.ac.jp
}

How to cite this paper: Shimizu, E., Shimoda, N., Kawamura, T., Ueda, N. and Kimura, K. (2020) Comparison of the Biological Activity and Constituents in Japanese Ambers. Advances in Biological Chemistry, 10, 99-112.

https://doi.org/10.4236/abc.2020.103008

Received: May 27, 2020

Accepted: June 27, 2020

Published: June 30, 2020

Copyright (c) 2020 by author(s) and Scientific Research Publishing Inc. This work is licensed under the Creative Commons Attribution International License (CC BY 4.0).

http://creativecommons.org/licenses/by/4.0/

\begin{abstract}
Background/Aim: Kuji amber is an interesting natural source for drug discovery because a new anti-allergic compound, named kujigamberol and several new compounds have been isolatated from it. It was important to evaluate the yield, biological activities and constituents of each methanol extract of Kuji, Iwaki, Choshi, Mizunami and Ube ambers in Japan in order to establish if additional new compounds could be identified in these ambers. Materials and Method: Biological activities of each extract were evaluated using growth-restoring activity of the mutant yeast strain involving $\mathrm{Ca}^{2+}$-signal transduction and inhibition activity of degranulation in rat basophilic leukemia (RBL)-2H3 cells. Constituents of each extract were analyzed by high performance liquid chromatography (HPLC). Results: All ambers except Ube amber have growth-restoring activity against the mutant yeast. Both Kuji and Iwaki ambers inhibited the degranulation of RBL-2H3 cells induced by the calcium ionophore A23187 in a dose dependent manner. The main biologically active compound in Kuji amber, kujigamberol, was also isolated from Iwaki amber and analyzed by mass spectrometry (MS) and nuclear magnetic resonance (NMR). Conclusion: Kuji and Iwaki ambers appeared to have the same origin. Choshi, Mizunami, and Ube ambers are valuable sources for biologically active compounds which are different from those of Kuji amber.
\end{abstract}

\section{Keywords}

Japanese Ambers, Kujigamberol, Growth Restoration of a Mutant Yeast, Inhibition of Degranulation, RBL-2H3 Cells

\section{Introduction}

Amber is polymerized and fossilized tree resin which is found worldwide and is ${ }^{*}$ Authors with equal contributions. 
important as a source of new biologically active compounds [1] [2]. Kuji amber from Japan [90 - 86 million years ago (Ma) (Prof. Hisao Ando, Ibaraki University, personal communication): Late Cretaceous] is a particularly unique amber, and we have isolated and identified five kinds of new biologically active compounds and one unusual known compound from it using the mutant yeast in-

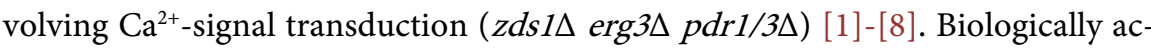
tive compounds from Baltic (56 - $34 \mathrm{Ma}$, Poland and Russia) [1], Dominican (45 - $30 \mathrm{Ma}$ and 20 - $15 \mathrm{Ma}$, Dominican Republic) [9] and Burmese (99 Ma, Burmese) [10] ambers have been isolated and identified. Biomarkars for Cretaceous ambers, amberene and 1-methylamberene without biological activities were also isolated and identified in Kuji amber and they were also detected in Burmese amber [11].

A main new compound from Kuji amber, named kujigamberol, has potent anti-allergic activity against a rhinitis model through the inhibition of $\mathrm{Ca}^{2+}$-influx and leukotriene $\mathrm{C} 4$ production in rat basophilic leukemia (RBL)-2H3 cells [12]. Thus, ambers from Japan such as Kuji amber are not only fascinating natural sources for the study of organic geochemistry, but also for drug screening. A question that arises is why we can isolate new compounds from Kuji amber but isolate only known compounds from Baltic, Dominican and Burmese ambers. As the environment of the earth on the Cretaceous-Paleogene (K-Pg) (formerly Cretaceous-Tertiary, K-T) boundary (65 Ma) changed to destroy most of plants and dinosaurs, the environment for the formation of Kuji amber that is older than the K-Pg boundary may be crucial for isolating new compounds. In contrast, both Baltic and Dominican ambers are younger than the K-Pg boundary. Additionally, no new compound, such as kujigamberol, has been isolated and detected from Burmese amber that is older than Kuji amber [10]. Recently it was reported that kujigamberol was not detected in the Upper Apitiam-Lower Albian amber deposit of the Peñacerrada II (Basque-Cantabrian Basin, Spain) [13]. Is the environment of the earth around Japan different from other regions? Thus, it is important to examine the biologically activity and their biologically active constituents in other Japanese ambers such as Iwaki (Late Cretaceous), Choshi (Early Cretaceous, $110 \mathrm{Ma}$ ), Mizunami (Pleistocene Quaternary, 16 - 15 $\mathrm{Ma}$ ) and Ube ambers (Cenozoic Paleogene Oligocene, $30 \mathrm{Ma}$ ) as compared to Kuji amber [Figure S1(a)].

In this study, we examined the biological activities and their constituents of Iwaki, Choshi, Mizunami and Ube ambers and compared them to those from Kuji amber.

\section{Materials and Methods}

General experimental procedure: Kuji amber was excavated from mines of Kuji Kohaku Co. Ltd. located in the upper part of the Tamagawa Formation of Kuji Group of Kuji city, Iwate Prefecture. The other Japanese ambers were excavated in small quantity from each area (Figure $\mathrm{S1}(\mathrm{a})$ ). The yeast strain is a de- 
rivative of strain W303-1A and is YNS17 (MATa zds1::TRP1 erg3::HIS3 pdr1::hisG URA3 hisG pdr3::hisG) [3] [4]. Difco ${ }^{\circledR}$ YPD broth and YPD agar were obtained from Becton Dickinson (Franklin Lakes, NJ, U.S.A.). FK506 (tacrolimus) was kindly provided by the Fujisawa Pharmaceutical Co., Ltd. (now Astellas Pharma Inc., Tokyo, Japan). Unless otherwise stated, chemicals used were of the best commercially available grade.

Biological activities of each ambers against the mutant yeast: All ambers were ground to a powder and extracted with methanol $(\mathrm{MeOH})$ for three days at $23^{\circ} \mathrm{C}$. After evaporation of the $\mathrm{MeOH}$, each dried extract was weighed. Extracted samples of $10 \mathrm{mg} / \mathrm{ml}$ in $\mathrm{MeOH}$ were prepared for subsequent assays. Screening was carried out using the YNS17 strain and $5 \mu$ of each sample was added to a plate as described previously [4]. The inhibitory activity of the $\mathrm{Ca}^{2+}$-signal transduction was determined by way of the strength and/or distinction of the yeast growth zone. An immunosuppressive drug, FK506 (2.5 ng/spot) was used as a positive control.

Biological activities of each ambers against the degranulation of RBL-2H3 cells: RBL-2H3 cells (ATCC CRL-2256, Manasass, VA, USA) were maintained in DMEM supplemented with 10\% heat-inactivated FBS (Hyclone Laboratories, Inc., Logan, UT, USA) and antibiotics [penicillin (50 units/mL)-streptomycin (50 $\mu \mathrm{g} / \mathrm{mL})$, Gibco, Thermo Fisher Scientific Inc., Waltham, MA, USA]. Cell viability was determined using the MTT [3-(4,5-dimethyl-2-thiazolyl)-2,5-diphenyl-2Htetrazolium bromide] assay (Dojindo Lab., Kumamoto, Japan). RBL-2H3 cells were plated in triplicate at a concentration of $3 \times 10^{4}$ cells/well in a 96-well plate and incubated overnight prior to treatment with various concentrations of each $\mathrm{MeOH}$ extract for $48 \mathrm{~h}$. Cytotoxicity was measured as described previously. RBL-2H3 cells were grown overnight in 96-well plates $\left(3 \times 10^{4}\right.$ cells/well) and the degranulation activity of each $\mathrm{MeOH}$ extract against them stimulated with the calcium ionophore A23187, was determined as described previously [12].

Isolation and identification of kujigamberol from Iwaki amber: Powdered Iwaki amber $(18.22 \mathrm{~g})$ was extracted with $\mathrm{MeOH}$ for 3 days at $23^{\circ} \mathrm{C}$ and the extract $[0.80 \mathrm{~g}(4.37 \%)]$ was diluted with water, followed by two extractions with one volume of ethyl acetate (EtOAc). After evaporation of the EtOAc, the organic layer [0.56 g (3.06\%)] was subjected to silica gel TLC (hexane:EtOAc $=3: 1$ as solvent). Active fractions ( $\mathrm{Rf}=0.45)$ were collected and concentrated under reduced pressure to afford crude material [49.3 $\mathrm{mg}(0.27 \%)$ ] which was further purified using high performance liquid chromatography (HPLC) [mobile phase $\mathrm{MeOH}: \mathrm{H}_{2} \mathrm{O}=85: 15$, flow rate $1 \mathrm{ml} / \mathrm{min}$, Capcell Pak $\mathrm{C}_{18}$ column $(4.6 \mathrm{~mm}$ i.d. $\times$ $150 \mathrm{~mm}$; Shiseido, Tokyo, Japan)]. Pure compound 1 [1.0 mg (0.054\%)] was obtained as a colorless oil [1].

Identification of 1 was performed using high resolution electron impact mass spectrometry (HREIMS) (JEOL JMS700) and nuclear magnetic resonance (NMR) (JEOL AL-400), including ${ }^{13} \mathrm{C}$ NMR and ${ }^{1} \mathrm{H}$ NMR. Ultra violet (UV) 
spectra in $\mathrm{MeOH}$ were measured on a UV mini 22 spectrophotometer (Shimadzu Co. Ltd., Kyoto, Japan). Compound 1 was compared with those of authentic kujigamberol [1] (Table S1).

Compound 1: Colorless oil. HREIMS $(\mathrm{m} / \mathrm{z})$ : $260.2138[\mathrm{M}]^{+}$(Calcd. for $\mathrm{C}_{18} \mathrm{H}_{28} \mathrm{O}: 260.2140$ ); ${ }^{1} \mathrm{H}-\mathrm{NMR}$ and ${ }^{13} \mathrm{C}$ NMR (Table S1).

HPLC analysis of kujigamberol, amberene and 1-methylamberene: HPLC analysis was performed using a mobile phase $\left[\mathrm{MeOH}: \mathrm{H}_{2} \mathrm{O}\right.$ (80:20) for kujigamberol and (90:10) for amberene and 1-methylambere] at a flow rate of $1 \mathrm{ml} / \mathrm{min}$, with a Capcell Pak $\mathrm{C}_{18}$ column [4.6 mm i.d. $\times 150 \mathrm{~mm}$ (Shiseido)], pump (PU-2080) and a photodiode array detector (MD-2018, JASCO Co., Tokyo, Japan).

\section{Results and Discussion}

The weight of the $\mathrm{MeOH}$ extract of each amber: The yield of the $\mathrm{MeOH}$ extract of Kuji, Iwaki, Choshi, Mizunami and Ube was 3.4\%, 4.4\%, 1.1\%, 26.7\% and $33.8 \%$, respectively. The yield of the $\mathrm{MeOH}$ extract from their domestic ambers is roughly proportional to each reported age [Figure S1(b)]. The $\mathrm{MeOH}$ extractable materials indicate non-polymerized (non-mature) amber.

Biological activity and its constituents: Comparison of the main constituents with biological activity (kujigamberol) and/or without biological activity (amberene and 1-methylamberene) in ambers by HPLC analysis indicated that Iwaki amber is similar to Kuji amber, but the growth-restoring activity and the HPLC analytical patterns of Choshi, Mizunami and Ube ambers were different from those of Kuji amber (Figure 1). The analytical HPLC pattern of three kinds of new biologically active compounds in Kuji amber (kujigamberol [1], kujiol A and kujigamberol B [5]) was almost the same as those of Iwaki amber. Although the $\mathrm{MeOH}$ extract of Choshi and Mizunami ambers had biological activity, those two peaks including three compounds were not detected [Figure 1(c) and Figure 1(d)]. These results suggest that biologically active compounds in Choshi and Mizunami ambers are different from those of Kuji amber and it is therefore worth isolating and identifying them further. However, there was no growth-restoring activity in the $\mathrm{MeOH}$ extract of Ube amber [Figure 1(e)].

The $\mathrm{MeOH}$ extract of Kuji amber (MEKA) inhibited the degranulation of RBL-2H3 cells by stimulation of thapsigargin $\left(\mathrm{IC}_{50}=15.0 \mu \mathrm{g} / \mathrm{ml}\right)$ and $\mathrm{A} 23187$ $\left(\mathrm{IC}_{50}=19.6 \mu \mathrm{g} / \mathrm{ml}\right)$ without cytotoxicity, but not by stimulation of immunoglobulin $\mathrm{E}(\mathrm{IgE})+2$,4-dinitrophenol (DNP)-bovine serum albumin (BSA) $\left(\mathrm{IC}_{50}>\right.$ $50.0 \mu \mathrm{g} / \mathrm{ml}$ ) [12]. Thus, the degranulation activity stimulated by A23187 was measured in each $\mathrm{MeOH}$ extract. Both $\mathrm{MeOH}$ extracts of Kuji and Iwaki amber showed almost the same inhibition activity against the degranulation (Figure 2). However, both the $\mathrm{MeOH}$ extract of Choshi and Ube ambers showed less activity than those of Kuji and Iwaki amber (Figure 2). Ube amber had inhibition activity against the degranulation, although it had no growth-restoring activity 
(a)
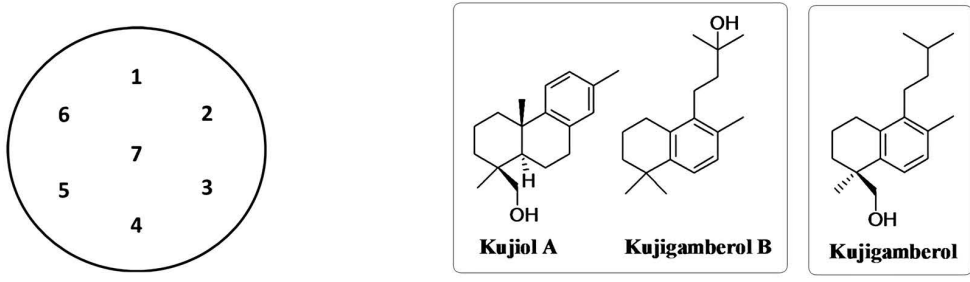

(b)

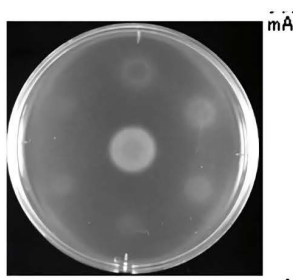

Kujiol A

Kujigamberol B

Kujigamberol
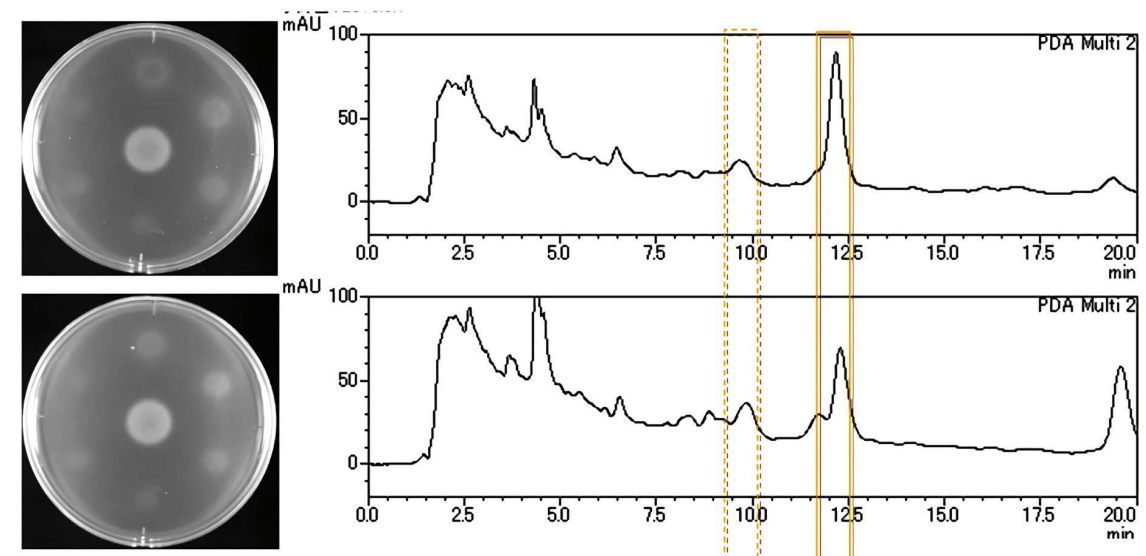

(c)
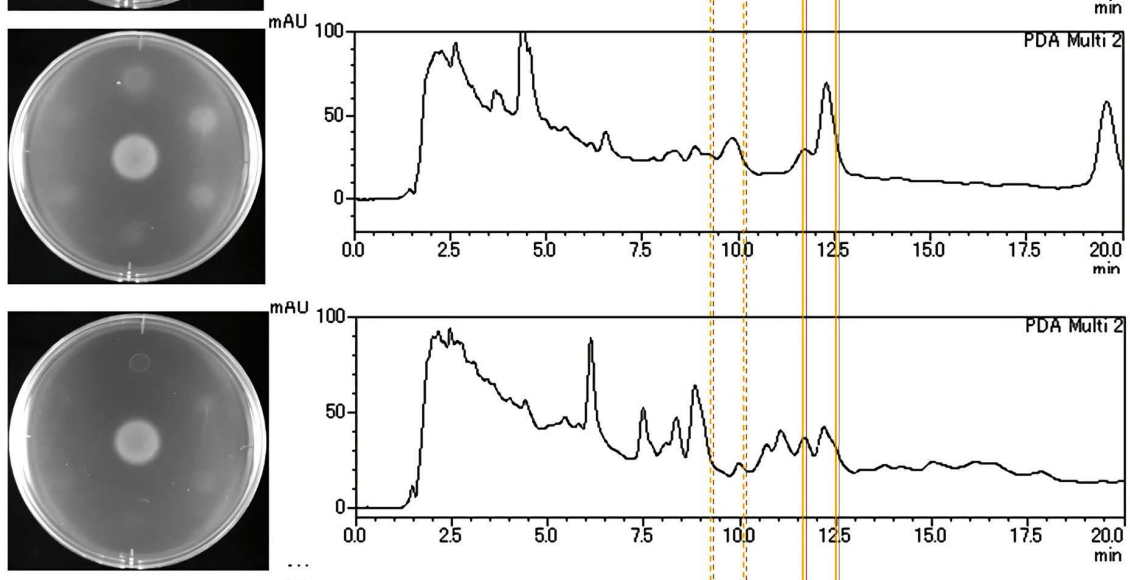

(d)
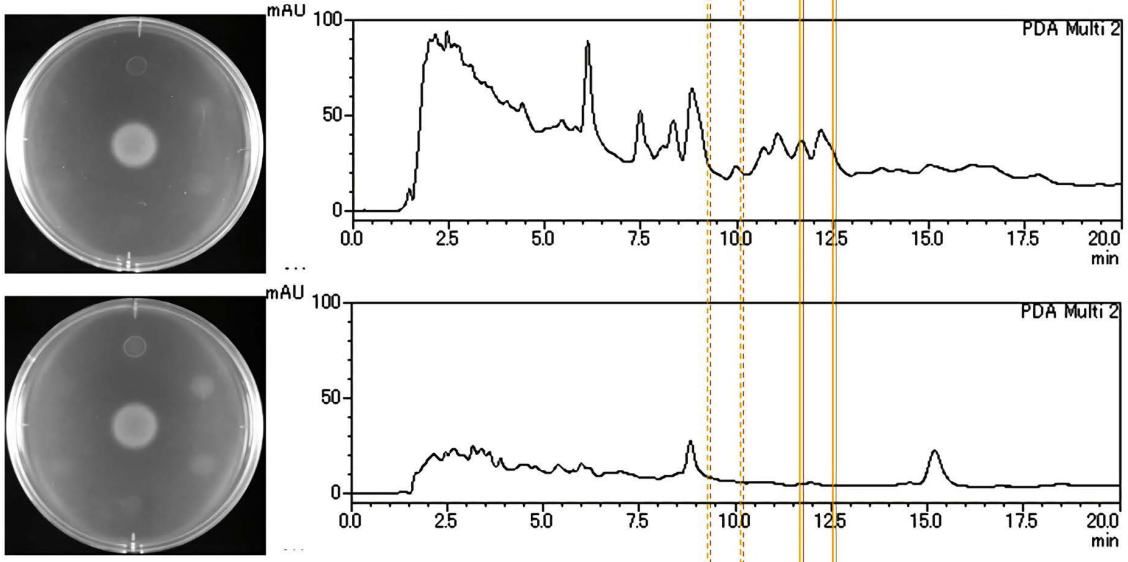

(e)
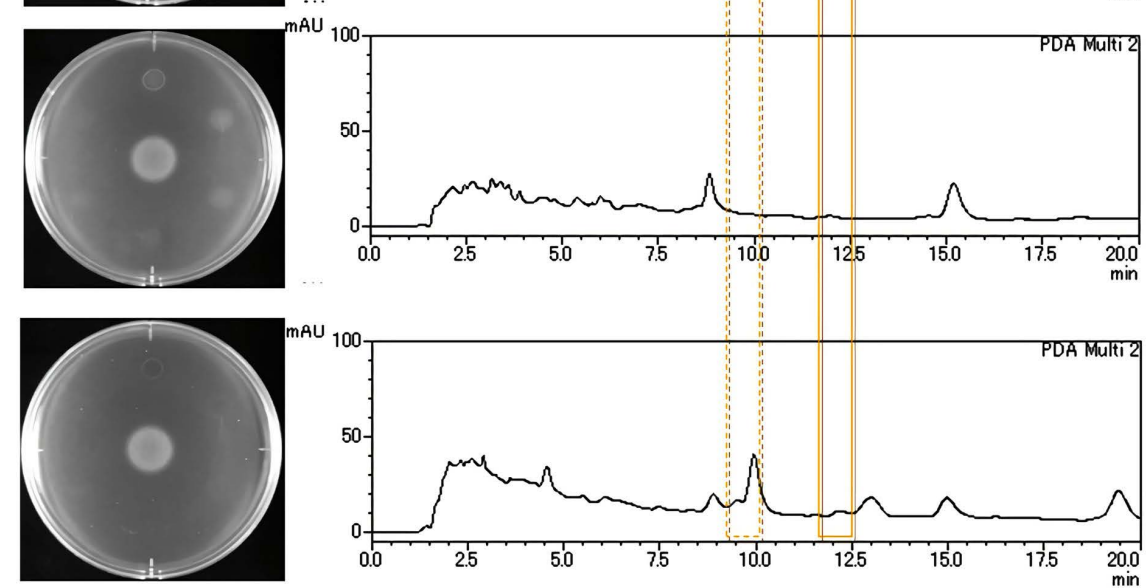

Figure 1. Growth-restoring activity against the mutant yeast and HPLC analytical pattern of each Japanese amber [(a) Kuji amber, (b) Iwaki amber, (c) Choshi amber, (d) Mizunami amber, (e) Ube amber]. The growth-restoring activities of each MeOH extract against YNS17 strain $(z d s 1 \Delta \operatorname{erg} 3 \Delta p d r 1 / 3 \Delta)$ were measured in the presence of $0.3 \mathrm{M} \mathrm{CaCl}_{2}[1: 5 \mu \mathrm{g} / \mathrm{spot}, 2$ : $2.5 \mu \mathrm{g} / \mathrm{spot}, 3: 1.25 \mu \mathrm{g} / \mathrm{spot}$, 4. $0.625 \mu \mathrm{g} / \mathrm{spot}, 5: 0.31 \mu \mathrm{g} / \mathrm{spot}$, 6: $0.16 \mu \mathrm{g} / \mathrm{spot}, 7: 2.5 \mathrm{ng} / \mathrm{spot}$ (FK506)]. HPLC analysis utilized a Capcell pak $\mathrm{C}_{18}(4.6 \times 150 \mathrm{~mm})$ column with $80 \% \mathrm{MeOH}$, flow rate at $1 \mathrm{ml} / \mathrm{min}, 100 \mu \mathrm{g}$ of each amber extract and a photodiode array (PDA) $(205 \mathrm{~nm}$ ). The solid line box shows a peak of kujigamberol and the dotted line box shows a peak of both kujiol A and kujigamberol B.

against YNS17 strain (Figure 1 and Figure 2). Although the $\mathrm{MeOH}$ extract of Mizunami amber showed growth-restoring activity against YNS17 strain, it had 


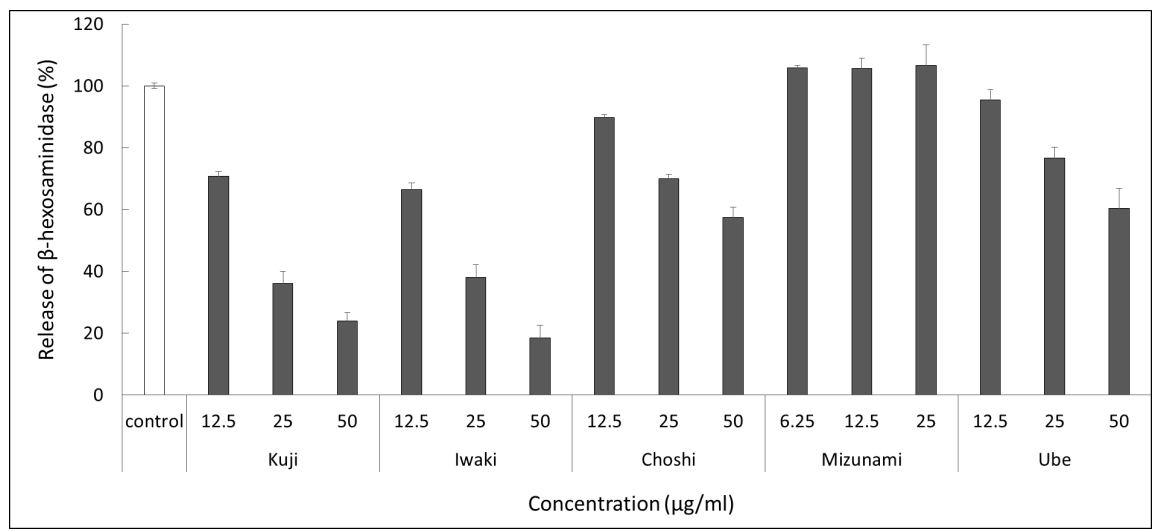

Figure 2. Degranulation activity of each $\mathrm{MeOH}$ extract against RBL-2H3 cells. RBL-2H3 cells were sensitized with $10 \mu \mathrm{L}$ A23187 (20 $\mu \mathrm{M})$ for $30 \mathrm{~min}$. Inhibition (\%) of $\beta$-hexosaminidase release by the sample was measured as absorbance at $405 \mathrm{~nm}$.

no inhibition activity against the degranulation (Figure 2).

Biologically active compounds and biomarkers in each amber: The peaks of kujigamberol, Kujiol A and kujigamberol B in MEKA were detected by HPLC of Iwaki amber. Both HPLC profiles showed a similar pattern. However, both HPLC traces of Choshi, Mizunami, and Ube ambers were different from those of Kuji and Iwaki ambers (Figure 1). These results suggested that Kuji amber and Iwaki amber are from the same origin. The biologically active compounds in Choshi, Mizunami and Ube ambers are different from each other and different from those of Kuji amd Iwaki ambers.

Amberene is one of biomarkers of Cretaceous amber and is detected in Kuji and Burmese ambers which are Late Cretaceous ambers [10]. It was detected in Iwaki amber by HPLC, but not identified in other ambers (Figure 3 ). This result was identical with each reported age.

Isolation and identification of kujigamberol from Iwaki amber: The main biologically active compound $\mathbf{1}$ in Iwaki amber was isolated from the $\mathrm{MeOH}$ extract for the first time as a colorless oil. The retention time (Figure S2), the UV spectrum (Figure S3) and the chemical shifts (Figures S4-S6, Table S1) of compound 1 and authentic kujigamberol showed the same values. They also showed clear and identical growth-restoring zones on the plate in a dose-dependent manner (from 0.5 to $0.031 \mu \mathrm{g} / \mathrm{spot}$ ) [Figure S7(a)]. Kujigamberol [Figure S7(b)] was also isolated and identified from Iwaki amber and this suggested that it is from the same origin as Kuji amber.

\section{Conclusion}

The yield of methanol soluble fraction decreased with the age of amber. All ambers except Ube amber have growth-restoring activity against the mutant yeast strain involving $\mathrm{Ca}^{2+}$-signal transduction. Both Kuji and Iwaki ambers inhibited the degranulation of RBL-2H3 cells induced by A23187 in a dose dependent manner. Kuji and Iwaki ambers appeared to have the same origin, because amberene 
(a)
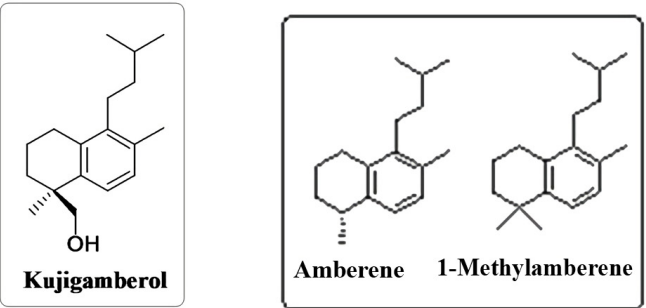

Kujigamberol

Amberene 1-Methylamberen

(b)

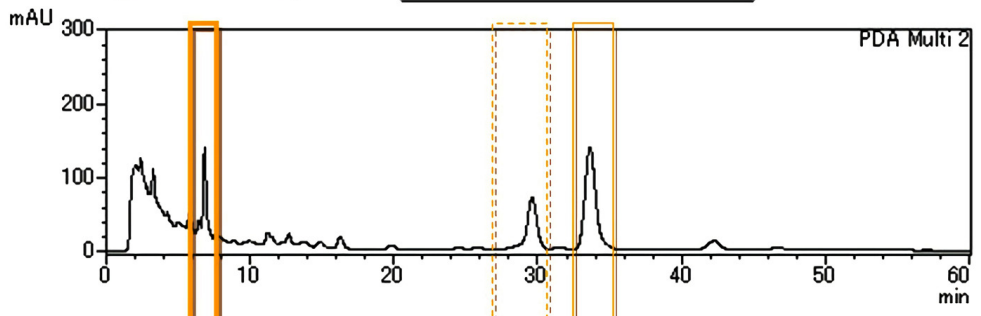

(c)

(d)

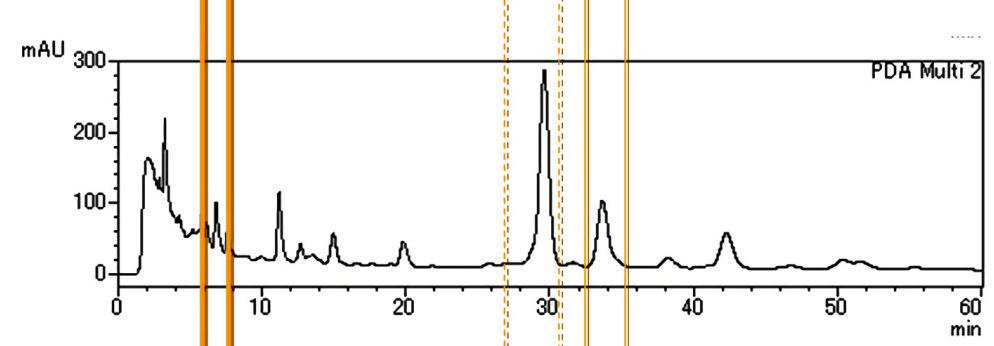

(e)
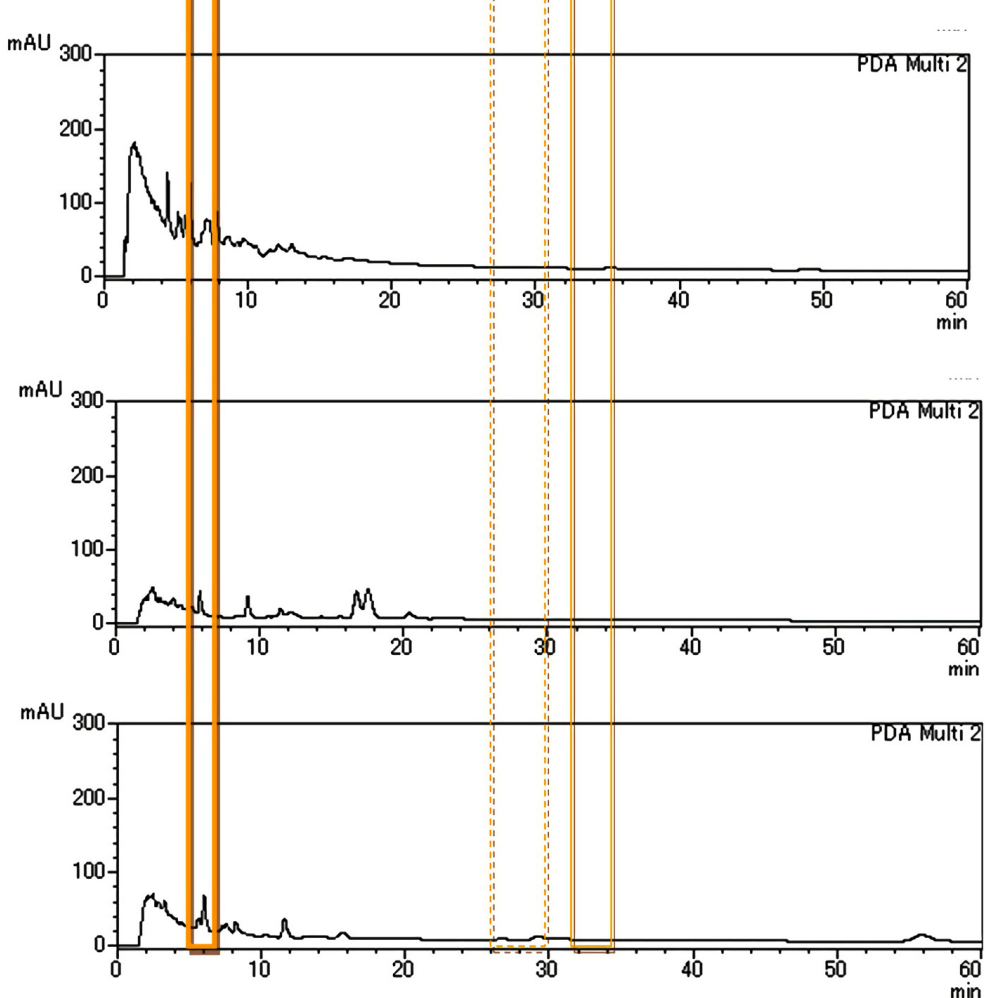

Figure 3. HPLC analytical pattern of amberene and 1-methylamberene in each $\mathrm{MeOH}$ extract [(a) Kuji amber, (b) Iwaki amber, (c) Choshi amber, (d) Mizunami amber, (e) Ube amber]. HPLC analysis utilized a Capcell pak $\mathrm{C}_{18}(4.6 \times 150 \mathrm{~mm})$ column with $80 \%$ $\mathrm{MeOH}$, flow rate at $1 \mathrm{ml} / \mathrm{min}, 100 \mu \mathrm{g}$ of each amber extract and a photodiode array (PDA) $(205 \mathrm{~nm})$. The solid line box shows a peak of kujigamberol, the dotted line box shows a peak of amberene and a solid line box shows a peak of 1-methyamberene. 
and 1-methlamberene were identified in both by HPLC. Additionally, the main biologically active compound in Kuji amber, kujigamberol, was also isolated from Iwaki amber and analyzed by MS and NMR. Choshi, Mizunami, and Ube ambers are therefore valuable sources for biologically active compounds which are different from those of Kuji amber.

\section{Acknowledgements}

We are grateful to Ms. Shizuko Nakajo from the Center for Regional Collaboration in Research and Education of Iwate University for HREIMS; to Prof. Hisao Ando, Ibaraki University for personal communications about Kuji amber; and to Emeritus Professor Tokichi Miyakawa of Hiroshima University for providing the YNS17 strain. We would like to thank Emeritus Professor Don R Phillips, La Trobe University for English language editing. This work was partially supported by Sanriku Fund, Japan Science and Technology Agency (JST) and the New Energy and Industrial Technology Development Organization (NEDO).

\section{Conflicts of Interest}

The authors declare no competing financial interest.

\section{References}

[1] Kimura, K., Minamikawa, Y., Ogasawara, Y., Yoshida, J., Saitoh, K., Shinden, H., Ye, Y.-Q., Takahashi, S., Miyakawa, T. and Koshino, H. (2012) Kujigamberol, a New Dinorlabdane Diterpenoid Isolated from 85 Million Years Old Kuji Amber Using a Biotechnological Assay. Fitoterapia, 83, 907-912. https://doi.org/10.1016/j.fitote.2012.03.024

[2] Kimura, K. (2019) Studies of Novel Bioprobes Isolated from Rare Natural Sources Using Mutant Yeasts. The Journal of Antibiotics, 72, 579-589. https://doi.org/10.1038/s41429-019-0189-5

[3] Shitamukai, A., Mizunuma, M., Hirata, D., Takahashi, H. and Miyakawa, T. (2000) A Positive Screening for Drugs That Specifically Inhibit the $\mathrm{Ca}^{2+}$-Signaling Activity on the Basis of the Growth Promoting Effect on a Yeast Mutant with a Peculiar Phenotype. Bioscience, Biotechnology, and Biochemistry, 64, 1942-1946. https://doi.org/10.1271/bbb.64.1942

[4] Ogasawara, Y., Yoshida, J., Shiono, Y., Miyakawa, T. and Kimura, K. (2008) New Eremophilane Sesquiterpenoid Compounds, Eremoxylarins A and B Directly Inhibit Calcineurin in a Manner Independent of Immunophilin. The Journal of Antibiotics, 61, 496-502. https://doi.org/10.1038/ja.2008.66

[5] Uchida, T., Koshino, H., Takahashi, S., Shimizu, E., Takahashi, H., Yoshida, J., Shinden, H., Tsujimura, M., Kofujita, H., Uesugi, S. and Kimura, K. (2018) $\mathrm{Ca}^{2+}$-Signal Transduction Inhibitors, Kujiol A and Kujigamberol B, Isolated from Kuji Amber Using a Mutant Yeast. Journal of Natural Products. 81, 1070-1074. https://doi.org/10.1021/acs.jnatprod.7b00922

[6] Takahashi, H., Koshino, H., Maruyama, M., Shinden, H. and Kimura, K. (2019) A Novel $\mathrm{Ca}^{2+}$-Signal Transduction Inhibitor, Kujigamberol C, Isolated from Kuji Amber. Bioscience, Biotechnology, and Biochemistry, 83, 1630-1934. https://doi.org/10.1080/09168451.2019.1611410 
[7] Takahashi, H., Shimoda, N., Koshino, H. and Kimura, K. (2019) Kujigamberoic Acid A, a Carboxylic Acid Derivative of Kujigamberol, Has Potent Inhibitory Activity against the Degranulation of RBL-2H3 Cells. Bioscience, Biotechnology, and Biochemistry, 83, 1193-1196. https://doi.org/10.1080/09168451.2019.1597616

[8] Shimizu, E., Koshino, H., Noro, A., Maruyama, M., Shimoda, N., Uesugi, S., Ohnishi, M. and Kimura (2019) Isolation of a Spirolactone Norditerpenoid as a Yeast $\mathrm{Ca}^{2+}$ Signal Transduction Inhibitor from Kuji Amber and Evaluation of Its Effects on PPM1A Activity. Fitoterapia, 134, 290-296.

https://doi.org/10.1016/j.fitote.2019.02.027

[9] Abe, T., Kobayashi, M., Okawa, Y., Inui, T., Yoshida, J., Higashio, H., Shinden, H., Uesugi, S., Koshino, H. and Kimura, K. (2016) Yeast $\mathrm{Ca}^{2+}$-Signal Transduction Inhibitors Isolated from Dominican Amber Prevent the Degranulation of RBL-2H3 Cells through the Inhibition of $\mathrm{Ca}^{2+}$-Influx. Fitoterapia, 113, 188-194.

https://doi.org/10.1016/j.fitote.2016.07.018

[10] Uchida, T., Koshino, H., Abe, J., Hakozaki, M., Yamada, H. and Kimura, K. (2019) Isolation of Yeast $\mathrm{Ca}^{2+}$ Signal Transduction Inhibitors from the Early Cretaceous Burmese Amber. Fitoterapia, 134, 422-428. https://doi.org/10.1016/j.fitote.2019.02.018

[11] Kawamura, T., Koshino, H., Nakamura, T., Nagasawa, Y., Nanao, H., Shirai, M., Uesugi, S., Ohno, M. and Kimura, K. (2018) Amberene and 1-Methylamberene, Isolated and Identified from Kuji Amber (Japan). Organic Geochemistry, 120, 12-18. https://doi.org/10.1016/j.orggeochem.2018.02.014

[12] Maruyama, M., Kobayashi, M., Uchida, T., Shimizu, E., Higashio, H., Ohno, M., Uesugi, S. and Kimura, K. (2018) Anti-Allergy Activities of Kuji Amber Extract and Kujigamberol. Fitoterapia, 127, 263-270. https://doi.org/10.1016/j.fitote.2018.02.033

[13] Menor-Salván, C., Simoneit, B.R.T., Ruiz-Bermejo, M. and Alonso, J. (2016) The Molecular Composition of Cretaceous Ambers: Identification and Chemosystematic Relevance of 1,6-Dimethyl-5-Alkyltetralins and Related Bisnorlabdane Biomarkers. Organic Geochemistry, 93, 7-21. https://doi.org/10.1016/j.orggeochem.2015.12.010 


\section{Appendix}
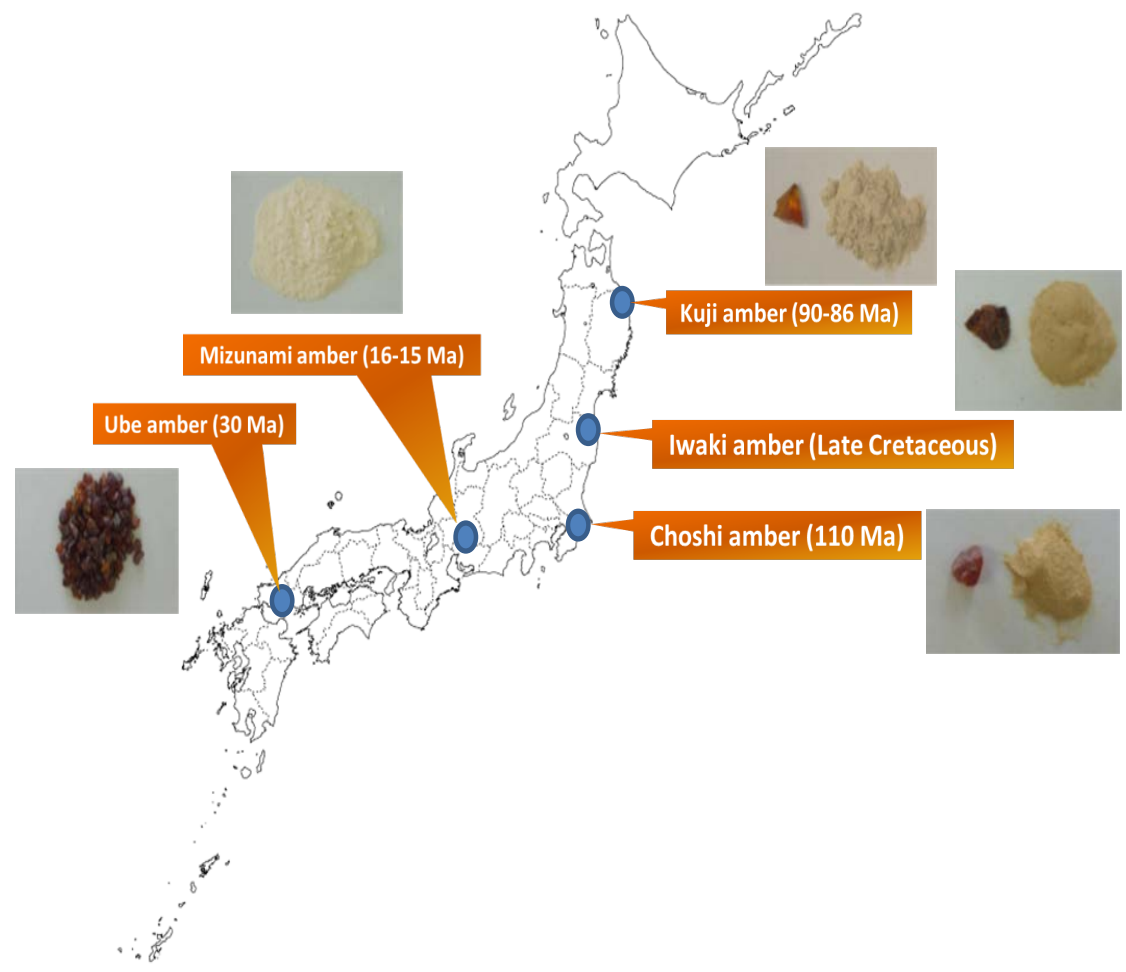

$0^{2}: \Delta$

(a)

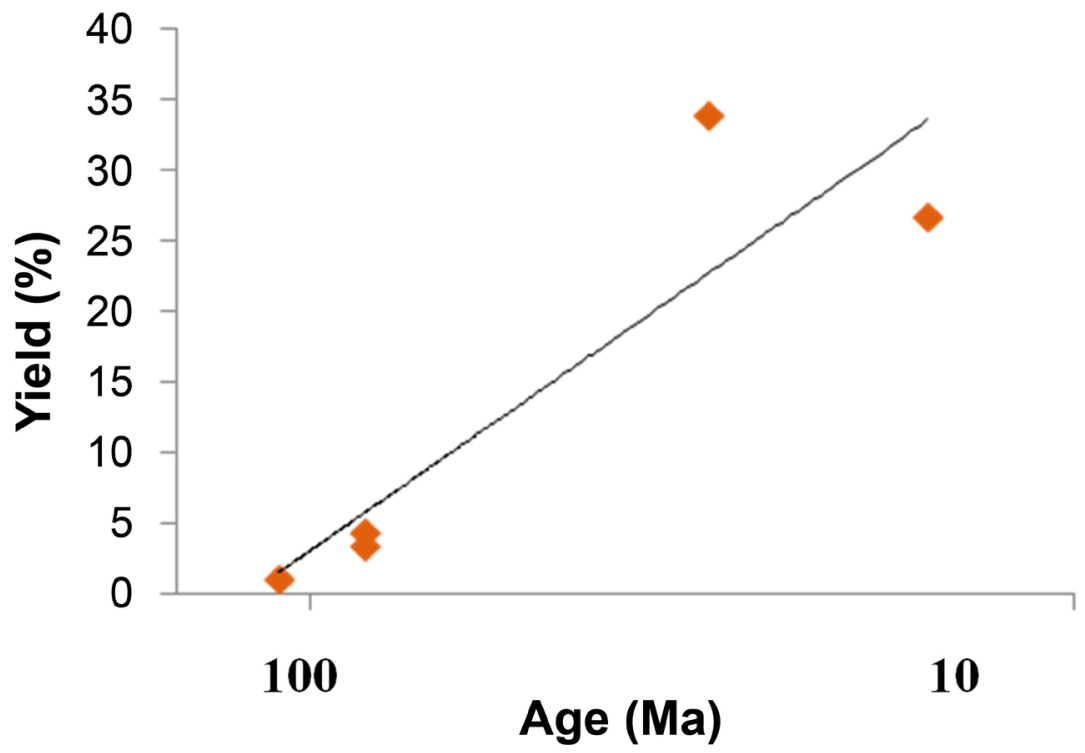

(b)

Figure S1. Location of Japanese ambers (a) and the relationship between the yield of $\mathrm{MeOH}$ extract and the age of the amber (b). 

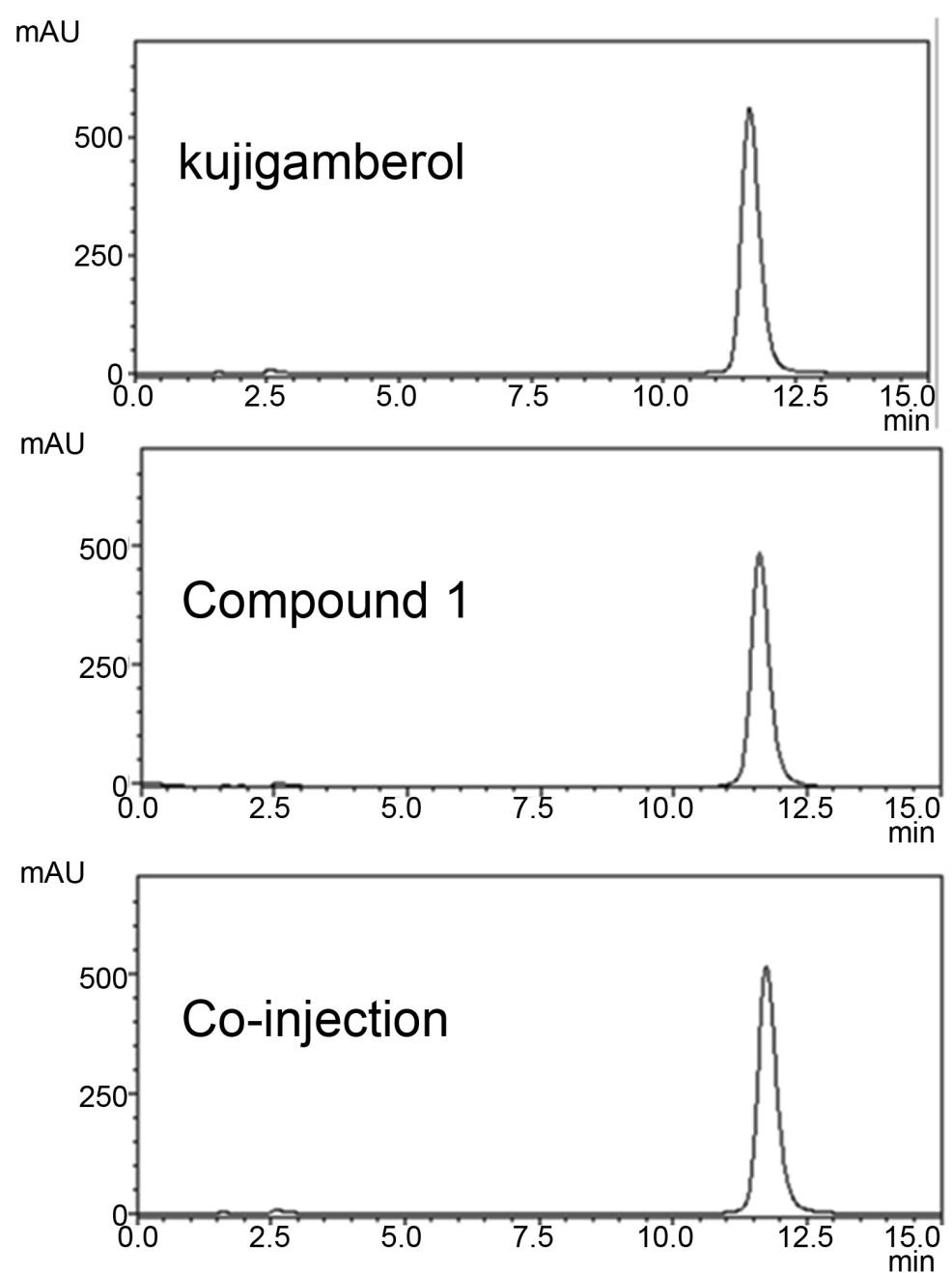

Figure S2. Co-injection with kujigamberol and compound 1 analyzed by HPLC. Column: Capcell Pak C18 (ODS $4.6 \mathrm{~mm} \times 150 \mathrm{~mm}$, TYPE UG $120 \AA$, $5 \mu \mathrm{m}$ ), Flow rate: $1.0 \mathrm{ml} / \mathrm{min}$, UV: PDA (205 nm), Injection: $2.5 \mu \mathrm{g}$ (co-injection: $1.25 \mu \mathrm{g}+1.25 \mu \mathrm{g})$.
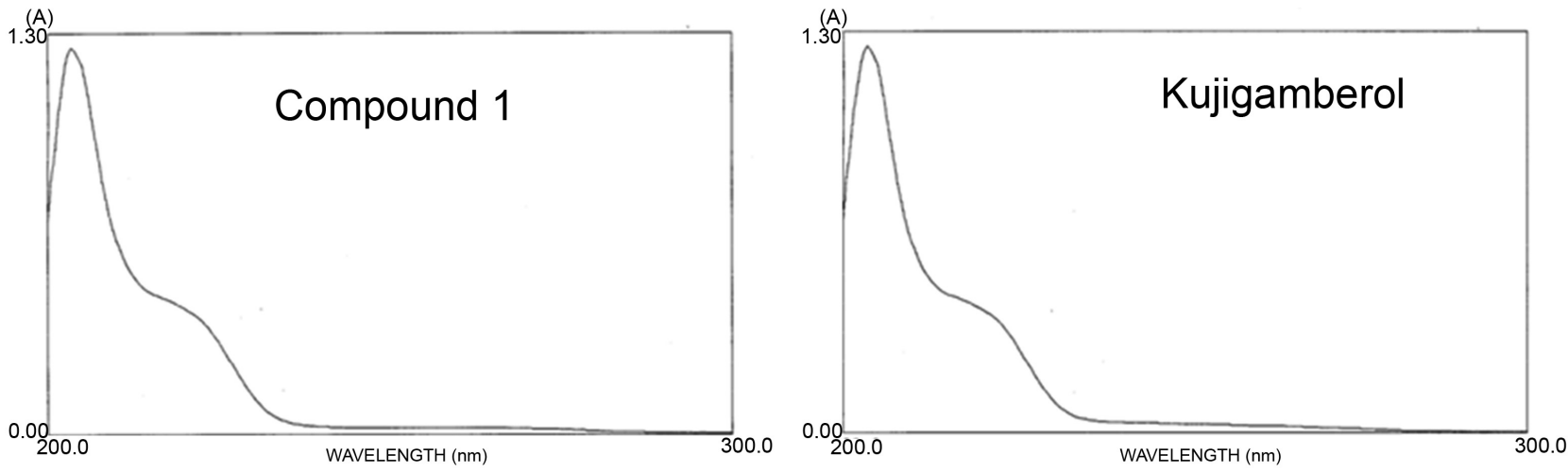

Figure S3. UV spectrum of compound 1 and kujigamberol $(100 \mu \mathrm{g} / \mathrm{ml}$ in $\mathrm{MeOH})$. 


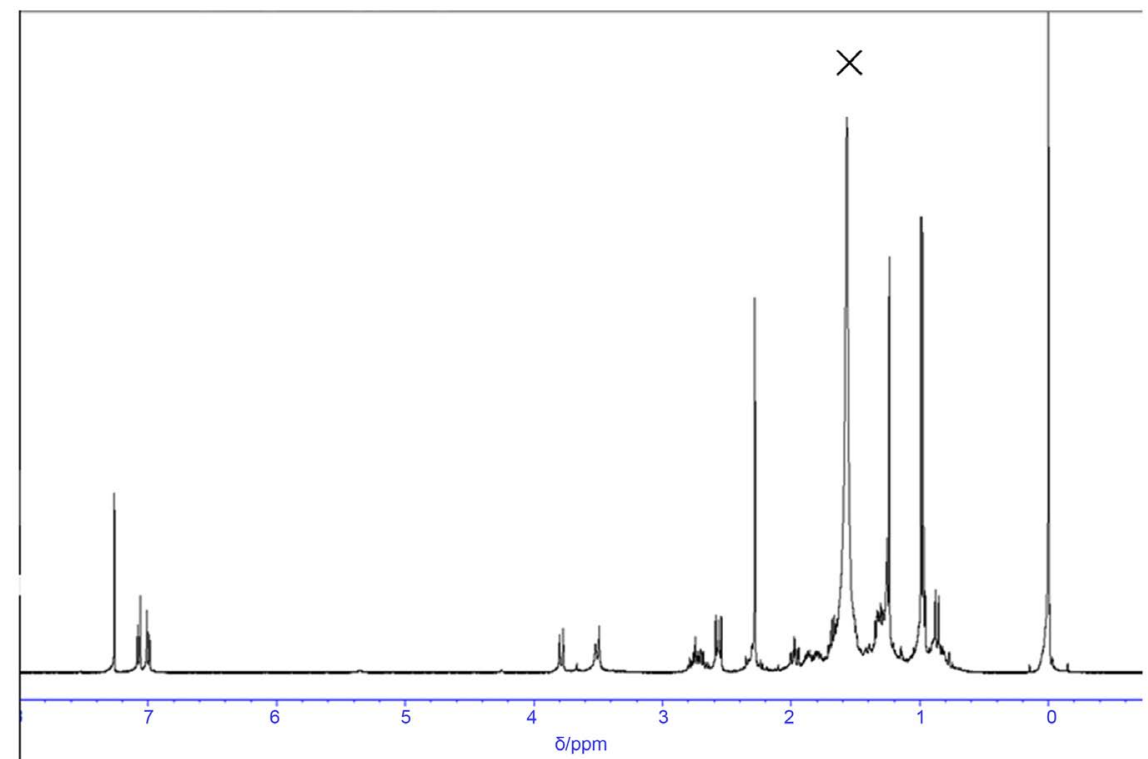

Figure S4. ${ }^{1} \mathrm{H}$ NMR spectrum of compound $1\left(\mathrm{CDCl}_{3}, 400 \mathrm{MHz}\right)$.

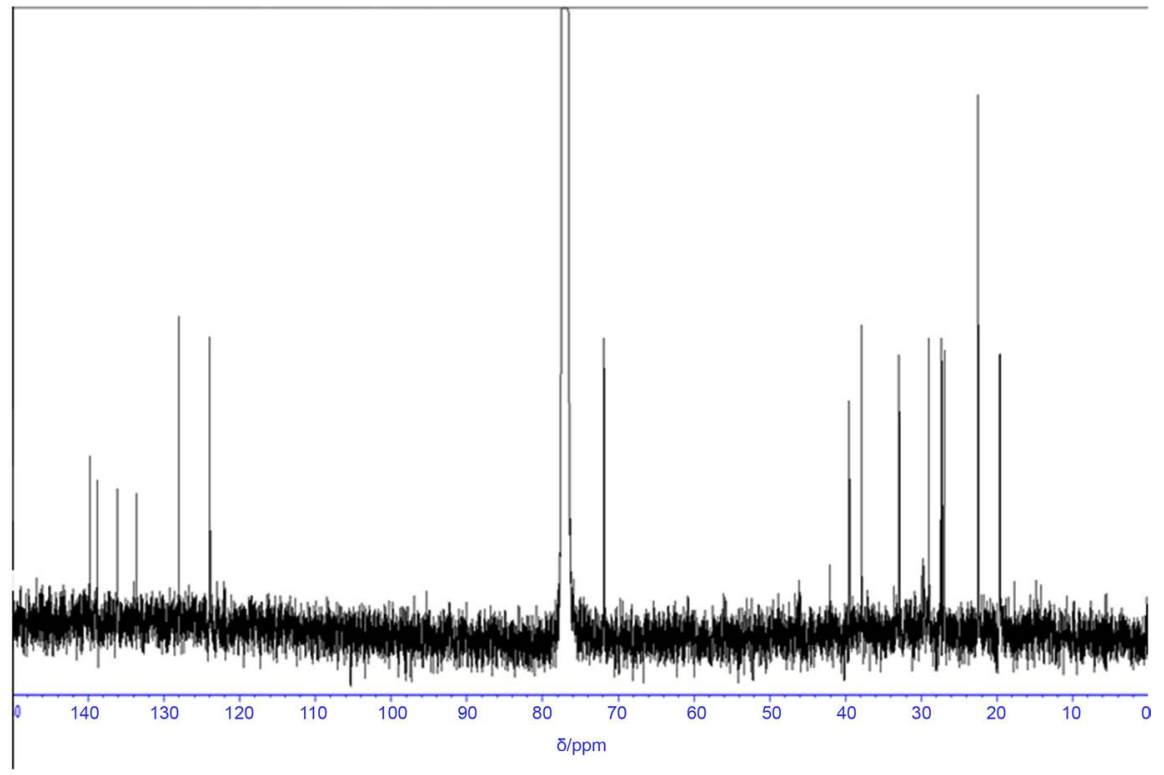

Figure S5. ${ }^{13} \mathrm{C}$ NMR spectrum of compound $1\left(\mathrm{CDCl}_{3}, 100 \mathrm{MHz}\right)$. 
(a) DEPT45

(b) DEPT90

(c) DEPT135
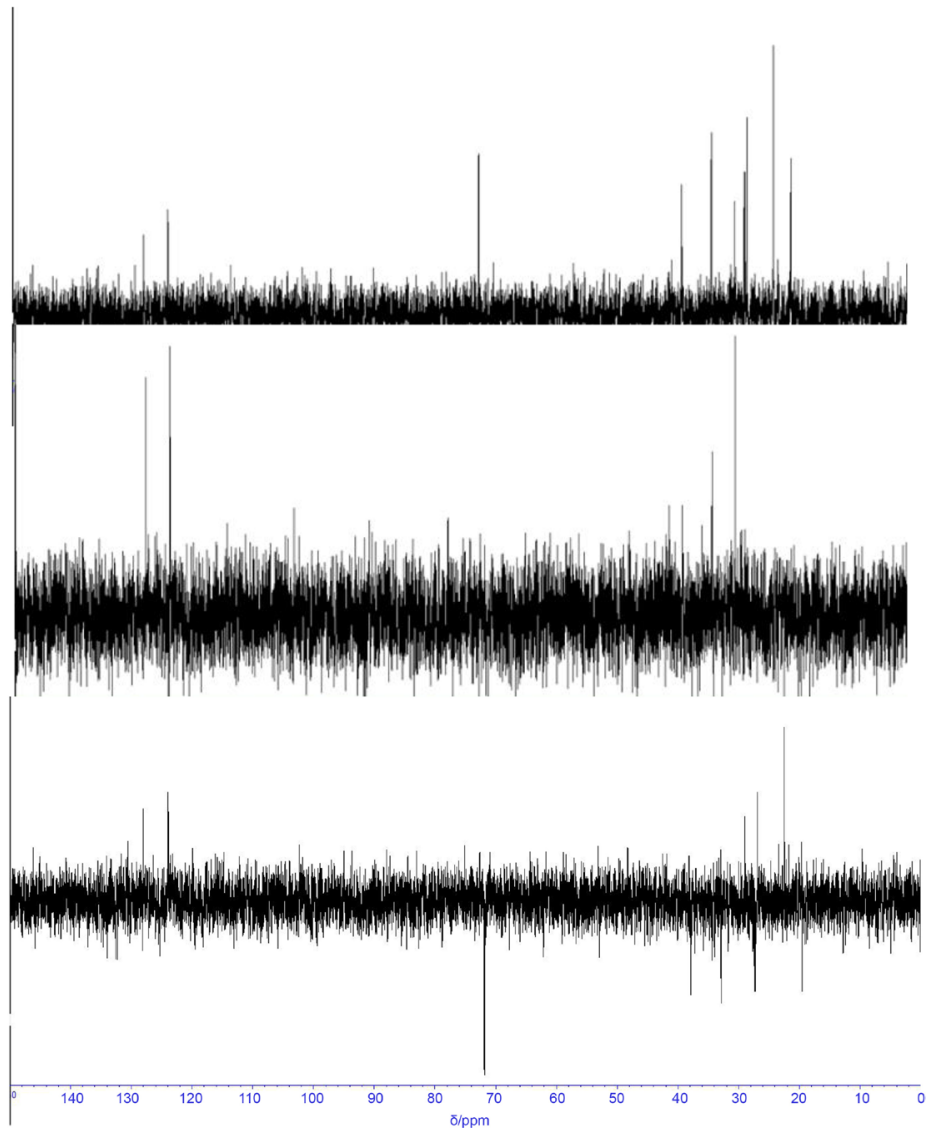

Figure S6. DEPT spectrum of compound $1\left(\mathrm{CDCl}_{3}\right)$.
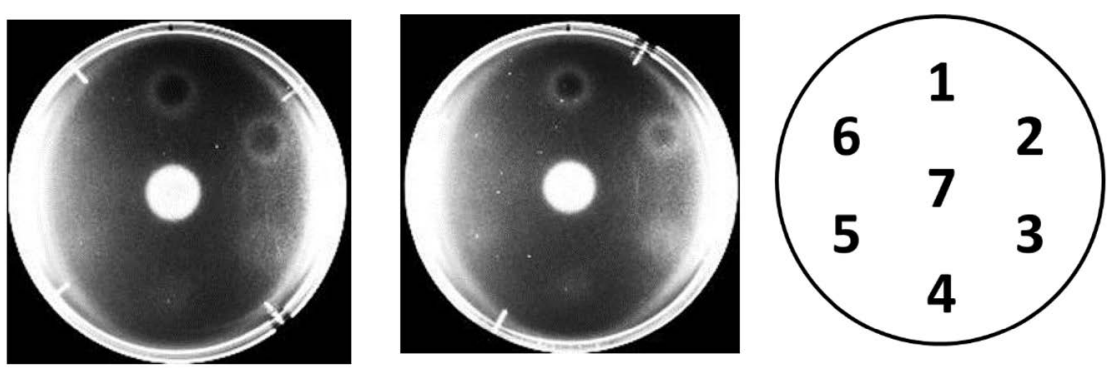

(a)<smiles>Cc1ccc2c(c1CCC(C)C)CCC[C@@]2(C)CO</smiles>

(b)

Figure S7. Growth-restoring activity and structure of 1. (a) Growth-restoring activities of 1 and kujigamberol against YNS17 strain ( $z d s 1 \Delta \operatorname{erg} 3 \Delta p d r 1 / 3 \Delta)$ in the presence of $0.3 \mathrm{M}$ $\mathrm{CaCl}_{2}$. 1: $0.5 \mu \mathrm{g} / \mathrm{spot}, 2: 0.25 \mu \mathrm{g} / \mathrm{spot}$, 3: $0.125 \mu \mathrm{g} / \mathrm{spot}$, 4. $0.0625 \mu \mathrm{g} / \mathrm{spot}$, 5: $0.031 \mu \mathrm{g} / \mathrm{spot}$, 6: $0.016 \mu \mathrm{g} / \mathrm{spot}, 7: 2.5 \mathrm{ng} / \mathrm{spot}$ (FK506). (b) The structure of 1 (kujigamberol). 
Table S1. Comparison of the chemical shifts between kujigamberol and compound 1 .

\begin{tabular}{|c|c|c|c|c|c|c|}
\hline & & & amberol $^{1)}$ & & Com & \\
\hline & $\delta_{\mathrm{C}}(\mathrm{ppm})$ & & $\delta_{\mathrm{H}}(\mathrm{ppm}, J$ in $\mathrm{Hz})$ & $\delta_{\mathrm{C}}(\mathrm{ppm})$ & & , $J$ in $\mathrm{Hz}$ ) \\
\hline 1 & 27.2 & 2.76 & $(\mathrm{H}, \mathrm{ddd}, 16.5,5.9,5.9)$ & 27.2 & 2.72 & $(\mathrm{H}, \mathrm{m})$ \\
\hline & & 2.68 & (H, ddd, $16.5,8.2,5.5)$ & & 2.70 & $(\mathrm{H}, \mathrm{m})$ \\
\hline 2 & 19.5 & 1.88 & $(\mathrm{H}, \mathrm{m})$ & 19.5 & 1.90 & $(\mathrm{H}, \mathrm{m})$ \\
\hline & & 1.79 & $(\mathrm{H}, \mathrm{m})$ & & 1.80 & $(\mathrm{H}, \mathrm{m})$ \\
\hline 3 & 32.9 & 1.52 & $(\mathrm{H}, \mathrm{m})$ & 32.9 & 1.47 & $(\mathrm{H}, \mathrm{m})$ \\
\hline & & 1.97 & $(\mathrm{H}, \mathrm{ddd}, 13.0,10.0,3.1)$ & & 1.96 & $(\mathrm{H}, \mathrm{m})$ \\
\hline 4 & 39.5 & & & 38.5 & & \\
\hline 5 & 138.8 & & & 138.8 & & \\
\hline 6 & 123.9 & 7.07 & $(\mathrm{H}, \mathrm{d}, 8.2)$ & 123.9 & 7.07 & $(\mathrm{H}, \mathrm{d}, 7.8)$ \\
\hline 7 & 128.0 & 7.00 & $(\mathrm{H}, \mathrm{br}, \mathrm{d}, 8.2)$ & 128.0 & 7.00 & $(\mathrm{H}, \mathrm{d}, 7.8)$ \\
\hline 8 & 133.6 & & & 133.7 & & \\
\hline 9 & 139.8 & & & 139.8 & & \\
\hline 10 & 136.1 & & & 136.1 & & \\
\hline 11 & 27.4 & 2.57 & $(2 \mathrm{H}, \mathrm{m})$ & 27.4 & 2.57 & $(2 \mathrm{H}, \mathrm{m}))$ \\
\hline 12 & 37.9 & 1.32 & $(2 \mathrm{H}, \mathrm{m})$ & 37.8 & 1.33 & $(2 \mathrm{H}, \mathrm{m})$ \\
\hline 13 & 29.0 & 1.68 & $(\mathrm{H}, \mathrm{m})$ & 29.0 & 1.66 & $(\mathrm{H}, \mathrm{m})$ \\
\hline 14 & 22.5 & 0.98 & $(3 \mathrm{H}, \mathrm{d}, 6.9)$ & 22.5 & 0.98 & $(3 \mathrm{H}, \mathrm{d}, 6.6)$ \\
\hline 15 & 22.5 & 0.98 & $(3 \mathrm{H}, \mathrm{d}, 6.9)$ & 22.5 & 0.98 & $(3 \mathrm{H}, \mathrm{d}, 6.6)$ \\
\hline 16 & 19.6 & 2.28 & $(3 \mathrm{H}, \mathrm{s})$ & 19.6 & 2.28 & $(3 \mathrm{H}, \mathrm{s})$ \\
\hline 17 & 26.9 & 1.24 & $(3 \mathrm{H}, \mathrm{s})$ & 26.9 & 1.24 & $(3 \mathrm{H}, \mathrm{s})$ \\
\hline 18 & 71.9 & 3.78 & $(\mathrm{H}, \mathrm{d}, 11.0)$ & 71.9 & 3.79 & $(\mathrm{H}, \mathrm{d}, 11.0)$ \\
\hline & & 3.51 & $(\mathrm{H}, \mathrm{d}, 11.0)$ & & 3.51 & $(\mathrm{H}, \mathrm{d}, 11.0)$ \\
\hline
\end{tabular}

